\title{
MODEL KONVERSI PELANGGAN UNTUK MENGGUNAKAN APLIKASI PEMESANAN MAKANAN MELALUI ATRIBUT PSIKOLOGIS DAN TEKNOLOGI
}

\author{
Novita Yolanda ${ }^{1}$, Bimmo Dwi Baskoro ${ }^{1 *}$, Jayadi ${ }^{1}$, Sudarmadji ${ }^{1}$ \\ ${ }^{1}$ Program Studi Manajemen, Sekolah Tinggi Manajemen Labora, Jakarta \\ *Alamat Email: bimmodibi@gmail.com
}

\begin{abstract}
ABSTRAK
Tujuan penelitian ini adalah untuk mengetahui pengaruh atribut psikologis dan teknologi pada konversi pelanggan untuk menggunakan aplikasi pemesanan makanan. Metode convenience sampling digunakan untuk mengumpulkan tanggapan dari responden. Sebanyak 374 responden telah dianalisis dengan pendekatan SEM-PLS. Hasil penelitian menunjukkan bahwa kemudahan penggunaan yang dirasakan, kegunaan yang dirasakan, insentif yang dirasakan, informasi yang dirasakan, manajemen hubungan pelanggan, dan sistem manajemen pesanan mempengaruhi konversi pelanggan secara signifikan. Kontribusi utama dari penelitian ini adalah analisis empiris atribut psikologis dan teknologi pada konversi pelanggan terhadap aplikasi pemesanan makanan khususnya di Jakarta.
\end{abstract}

Kata Kunci: aplikasi, atribut psikologis, atribut teknologi, konversi pelanggan, Jakarta

\begin{abstract}
The purpose of the study was to find out the effect of psychological and technological attributes on customer conversions to use food ordering apps. Convenience sampling methods are used to collect responses from respondents. A total of 374 respondents have been analyzed with the SEM-PLS approach. The results showed that perceived ease of use, perceived usability, perceived incentives, perceived information, customer relationship management, and order management systems significantly affected customer conversions. A major contribution of the study was an empirical analysis of psychological and technological attributes to customer conversion to food ordering applications particularly in Jakarta.
\end{abstract}

Keywords: apps, psychological attributes, technology attributes, customer conversions, Jakarta

\section{A. PENDAHULUAN}

Di era saat ini, aplikasi seluler telah menembus pasar Jakarta dengan mulus karena ketersediaan Internet berkecepatan tinggi dengan harga ekonomis. Saat ini pelanggan menggunakannya secara signifikan untuk berbagai kegiatan seperti belanja, hiburan, perbankan, jejaring sosial dan bahkan untuk memesan makanan (Yang, Liu, Li, \& Yu, 2015). Pasar Indonesia dianggap sebagai salah satu pasar smartphone dengan pertumbuhan tercepat secara global. Sebuah laporan dari 
Newzoo yang dikutip oleh Katadata (2021) menunjukkan bahwa ada sekitar 160,23 juta pengguna smarphone di Indonesia. Karena penetrasi teknologi ini diprediksi bahwa bisnis pemesanan makanan online akan meningkat drastis dari tahun ke tahun (Medcom, 2021).

Saat ini pasar Jakarta untuk pelanggan seluler muda meningkat setiap hari dengan lebih banyak ketergantungan pada aplikasi ritel online. Pikiran pelanggan selalu siap untuk mengadopsi teknologi baru dan perilaku mereka cenderung berubah dengan lingkungan yang berubah (Atulkar \& Kesari, 2018). Studi menunjukkan bahwa sebagian besar pemain masuk ke dalam bisnis ini dan mengembangkan komunikasi langsung yang efektif, persuasif, langsung, loyalitas merek (Atulkar \& Kesari, 2017; Iyer, Blut, Xiao, \& Grewal, 2020) dan kesadaran merek di kalangan pengguna, menghasilkan penjualan dan pertumbuhan merek. Telah diamati bahwa di antara berbagai aplikasi pemesanan makanan yang tersedia, pelanggan menggunakan beberapa aplikasi tertentu tergantung pada kesesuaiannya berdasarkan beberapa atribut yang ditawarkan oleh aplikasi yang mempengaruhi keputusan pembelian pelanggan (Wang, Tseng, Wang, Shih, \& Chan, 2019). Ada beberapa penelitian yang mengeksplorasi atribut yang mempengaruhi adopsi dan penggunaan aplikasi pemesanan makanan di masa lalu (Kapoor \& Vij, 2018; Malik, Suresh, \& Sharma, 2017; Teller, Brusset, \& Kotzab, 2019), tetapi tetap saja, ada ruang untuk menambahkan beberapa atribut penting baru ke arah penelitian lebih lanjut ini.

Berdasarkan model penerimaan teknologi (TAM) (Davis, 1989), penelitian sebelumnya hanya berfokus pada atribut psikologis yang mempengaruhi adopsi $\mathrm{m}$ commerce (Ho, Wu, Lee, \& Pham, 2020; Shankar \& Datta, 2018). Sementara kontrol, norma subjektif, atribut budaya, rangsangan eksternal, perasaan emosional, harapan kinerja (Ye \& Liu, 2017), dan efikasi diri adalah beberapa atribut lain yang mempengaruhi kegiatan operasional $m$-commerce dan memicu kognisi internal pelanggan. Oleh karena itu, hal ini menghasilkan niat pembelian pelanggan dari aplikasi online (Malik et al., 2017; Teller et al., 2019) dan menunjukkan konversi pelanggan. Beberapa penelitian berfokus terutama pada atribut teknis aplikasi (Kapoor \& Vij, 2018; Yang et al., 2015) dan dampaknya terhadap niat pembelian pelanggan dan perilaku pembelian yang sebenarnya. Demikian pula, studi Singh et al. (2020) mengidentifikasi dampak atribut teknologi dan budaya bersama dengan beberapa variabel tambahan seperti gender dan etnis.

Saat ini pelanggan dipengaruhi oleh beberapa atribut lagi secara bersamaan, yang tidak dapat diabaikan oleh penyedia layanan, karena harapan pelanggan terus berubah seiring waktu dan teknologi yang tersedia (Atulkar, 2020), memotivasi perusahaan untuk selalu memperbarui aplikasi untuk menawarkan layanan yang lebih baik dalam bisnis aplikasi 
seluler yang berkembang pesat ini (E. Taylor, 2016; Yang et al., 2015). Penelitian terkait konversi pelanggan dalam penggunaan aplikasi pemesanan makanan dengan pendekatan atribut psikologi dan teknologi belum pernah dilakukan khususnya di Jakarta. Oleh karena itu, tujuan utama dari penelitian ini adalah untuk mengidentifikasi pengaruh psikologis (seperti persepsi kemudahan penggunaan, persepsi kegunaan, persepsi insentif, dan persepsi harga) dan atribut teknologi (seperti desain visual, persepsi informasi, manajemen hubungan pelanggan, dan sistem manajemen pesanan) pada konversi pelanggan (Gambar 1) karena gaya hidup pelanggan berubah dengan cepat dan mereka menghindari mengunjungi restoran untuk makanan terutama saat akhir pekan. Dengan demikian, aplikasi pemesanan makanan dianggap sebagai solusi yang lebih baik untuk memenuhi masalah penelitian ini.

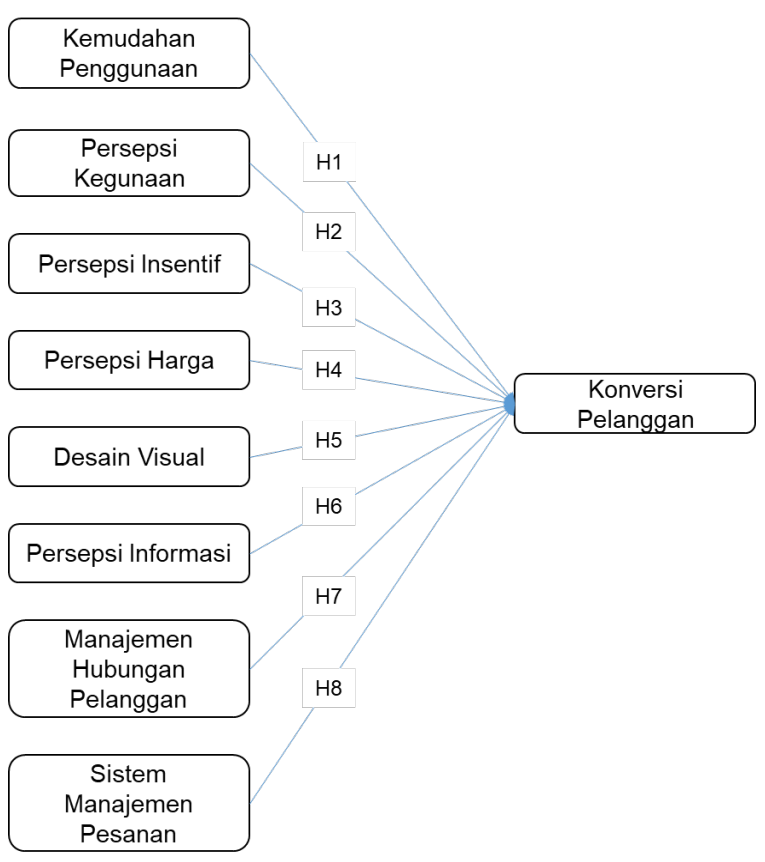

Gambar 1. Model Penelitian

\section{B. TINJAUAN PUSTAKA DAN PENGEMBANGAN HIPOTESIS}

\section{Kemudahan Penggunaan}

Menurut Davis et al. (1992), persepsi kemudahan penggunaan adalah tingkat kepercayaan yang ditunjukkan pelanggan pada saat pembelian bahwa lebih mudah digunakan dan ditangani. Studi menunjukkan bahwa persepsi pelanggan tentang teknologi tertentu yang lebih mudah, jelas dan dapat dimengerti memotivasi pengguna untuk menggunakan teknologi online dengan terampil. Fitur kemudahan penggunaan yang dirasakan ini telah diadopsi oleh Davis et al. (1992) dengan model adopsi teknologi (TAM) dan selanjutnya diteruskan oleh Chen (2008) dan ditemukan sangat penting untuk adopsi aplikasi pembayaran dan penggunaannya. Demikian pula, beberapa penelitian lain (Shankar \& Datta, 2018) di sektor m-commerce dan perbankan juga menyarankan bahwa kemudahan penggunaan yang dirasakan terbukti menjadi elemen penting bagi pengguna dalam menentukan adopsi dan niat untuk menggunakan teknologi aplikasi seluler (Madan \& Yadav, 2018; N. Singh et al., 2020). Penelitian lainnya juga mengidentifikasi bahwa pada titik penjualan ritel, konsep ini memainkan peran penting dalam adopsi dan penggunaan layanan pembayaran berbasis mobile (Apanasevic, Markendahl, \& Arvidsson, 2016; Arvidsson, 2014). Oleh karena itu, telah disarankan bahwa teknologi aplikasi mobile harus mudah dimengerti (Kim, Xu, \& Gupta, 2012; Marriott \& 
Williams, 2018), yang secara langsung atau tidak langsung mempengaruhi perilaku pembelian konsumen dan mengubahnya untuk mengadopsi teknologi aplikasi seluler untuk pembelian mereka. Oleh karena itu, penelitian ini mengusulkan hipotesis berikut.

H1. Persepsi kemudahan penggunaan memiliki hubungan positif dan signifikan dengan konversi pelanggan.

\section{Persepsi Kegunaan}

Studi menunjukkan bahwa pelanggan mengadopsi teknologi spesifik jika mereka menemukan teknologi harus berguna bagi mereka (Apanasevic et al., 2016; Madan \& Yadav, 2018) dan akan meningkatkan efisiensi dan efektivitasnya terhadap pembelian. Menurut Kim et al., (2012), dengan menggunakan teknologi m-payment pelanggan dapat menyelesaikan tugas mereka dengan cepat, nyaman, dan merasa senang menggunakan teknologi itu. Persepsi kegunaan adalah persepsi tingkat utilitas teknologi pembayaran secara mobile (N. Singh et al., 2020) yang meningkatkan profitabilitas dan probabilitas niat pengguna untuk meningkatkan kegunaan teknologi tersebut dalam memesan makanan (Hagberg, Sundstrom, \& Egels-Zandén, 2016; Shankar \& Datta, 2018). Pelanggan dapat mengambil bantuan teknologi yang berguna tersebut untuk meningkatkan kegunaan dan nilai-nilai mereka (Kim et al., 2012) karena aplikasi pemesanan makanan memfasilitasi pengguna untuk dengan mudah membayar tagihan mereka (Liu \& Dewitte, 2021) dan belanja online langsung tanpa masalah (Arvidsson, 2014). Dengan demikian, persepsi kegunaan memiliki dampak positif dan penting pada adopsi dan persepsi kegunaan. Oleh karena itu, pengguna saat ini mengadopsi teknologi ini (Madan \& Yadav, 2018; N. Singh et al., 2020) di tempat kerja rutin sehari-hari mereka dan kegunaan teknologi tersebut dianggap sebagai salah satu atribut penting untuk mengadopsi aplikasi pemesanan makanan dan mengusulkan hipotesis berikut.

H2. Persepsi kegunaan memiliki hubungan positif yang signifikan dengan konversi pelanggan.

\section{Persepsi Insentif}

Menurut Malik et al. (2017), insentif adalah manfaat moneter yang ditawarkan kepada pelanggan dalam bentuk kupon diskon, hadiah cash back, penawaran penjualan, diskon loyalitas, penawaran promosi, kupon rujukan dan poin bonus loyalitas (Ting, Yacob, Liew, \& Lau, 2016; Ünal, Erciş, \& Keser, 2011). Hal ini hanya mungkin melalui kolaborasi dengan pemain keuangan lain di pasar yang menawarkan layanan diskon (Johnson, Kiser, Washington, \& Torres, 2018; Kapoor \& Vij, 2018). Pelanggan mendapat diskon khusus ketika mereka menggunakan kartu kredit / debit mereka, internet banking, dan aplikasi $m$ payment tertentu untuk membayar tagihan (Taylor \& Levin, 2014) untuk memesan makanan. Telah diamati bahwa pelanggan di 
Jakarta sensitif terhadap harga dan jenis penawaran dan layanan ini (Harwani \& Fauziyah, 2020) secara positif memotivasi mereka dalam mengembangkan sikap untuk menggunakan aplikasi pemesanan makanan dan divalidasi oleh peneliti sebelumnya (Ashish Kumar, Dhingra, Batra, \& Purohit, 2020). Di sisi lain studi memvalidasi kenyamanan pelanggan untuk menggunakan semua fasilitas ini karena pelanggan bersemangat terus mencari penawaran menarik, insentif yang disediakan oleh aplikasi pemesanan makanan dan memotivasi mereka untuk menggunakan aplikasi ini dalam waktu dekat juga (Reimers \& Clulow, 2009). Oleh karena itu, penelitian ini menyajikan hipotesis berikut.

H3. Persepsi insentif memiliki hubungan positif yang signifikan dengan konversi pelanggan.

\section{Persepsi Harga}

Studi mengamati bahwa selama proses belanja pelanggan selalu membandingkan harga produk atau layanan dengan pesaing lain di pasar (Kim et al., 2012; D. G. Taylor \& Levin, 2014) dan kemudian menafsirkan hadiah yang ditawarkan sebagai ekonomis atau mahal. Para peneliti juga menyarankan agar pelanggan mengembangkan selera harga mereka dengan membandingkan layanan (Atulkar, 2019; Shankar \& Kumari, 2016) dan kemudian membuat keputusan pembelian berdasarkan harga yang dirasakan (Johnson et al., 2018). Oleh karena itu, pelanggan selalu memutuskan kualitas produk dan layanan berdasarkan harga yang dirasakan, bahkan pada tidak tersedianya nama merek atau informasi relevan lainnya (Osei-Frimpong, 2019; Ünal et al., 2011). Studi penelitian sebelumnya (Olivier \& Terblanche, 2016) menunjukkan bahwa biaya yang dirasakan dianggap sebagai faktor penting dan vital bagi pengguna untuk aplikasi pemesanan makanan. Utilitas transaksi dan harga yang dirasakan (Kapoor \& Vij, 2018) oleh pelanggan berdampak negatif atau positif pada nilai-nilai yang dirasakan oleh pelanggan (Wang et al., 2019). Pelanggan juga mengamati bahwa harga yang lebih tinggi membuat mereka merasakan kualitas yang lebih tinggi untuk produk atau layanan memotivasi mereka untuk membandingkan kualitas dengan alternatif, karena mereka tampaknya lebih memperhatikan pengurangan harga, sambil memesan makanan dari aplikasi pemesanan makanan. Oleh karena itu, penelitian ini menyajikan hipotesis berikut.

H4. Persepsi harga memiliki hubungan positif yang signifikan dengan konversi pelanggan.

\section{Desain Visual}

Desain visual memiliki fitur aplikasi penting (Singh, 2019) yang dikembangkan untuk memotivasi pelanggan untuk menggunakan aplikasi pemesanan makanan. Menurut Kim et al. (2012), desain visual adalah kombinasi dari warna yang menarik, huruf, ukuran huruf, visual, desain, gambar, informasi, tampilan, dan lain- 
lain yang membuat aplikasi tampan, indah, mengesankan, dan kompatibel untuk pelanggan (Shankar \& Kumari, 2016). Studi menunjukkan bahwa desain visual mempengaruhi pelanggan untuk sebagian besar selama pembelian online (A. Kumar \& Anjaly, 2017; R. Singh, 2019). Daya tarik visual desain situs memberikan komunikasi yang konstruktif kepada pelanggan tentang kualitas vendor dan produk yang ditawarkan. Hal itu harus menjadi pilihan pengguna dan antarmuka aplikasi yang membuat pelanggan merasa nyaman (Ünal et al., 2011; Wang et al., 2019) dan informatif untuk menggunakan teknologi aplikasi seluler. Informasi dan fitur visual dari aplikasi menyebabkan tanggapan psikologis tertentu pada pengguna untuk menggunakan aplikasi pemesanan makanan dan memotivasi orang lain untuk melakukannya (Yang et al., 2015). Oleh karena itu, aplikasi dengan desain visual yang buruk menghambat keterlibatan pengguna dengan aplikasi pemesanan makanan tertentu dan menyajikan hipotesis berikut.

H5. Desain visual memiliki hubungan positif yang signifikan dengan konversi pelanggan.

\section{Persepsi Informasi}

Menurut Yang et al. (2015), kualitas informasi mengacu pada kebenaran, kelengkapan, penampilan dan informasi komprehensif tentang produk atau layanan yang dibagikan oleh pemain ritel online. Penelitian sebelumnya menunjukkan bahwa persepsi informasi mengubah pelanggan menuju aplikasi pemesanan makanan (Ünal et al., 2011; Wang et al., 2019) dan memotivasi mereka untuk menunjukkan perilaku pembelian dari aplikasi pemesanan makanan (Yeo, Tan, Teo, \& Tan, 2021). Kualitas dan struktur informasi bersama dengan layanan yang disediakan oleh penyedia layanan online melalui aplikasi seluler berdampak pada kepuasan dan loyalitas pelanggan (Elliot, Li, \& Choi, 2013) terhadap aplikasi pemesanan makanan tertentu. Kualitas informasi yang tersedia di aplikasi atau situs pemesanan makanan meningkatkan tingkat keterlibatan pelanggan (Savastano, Bellini, D'Ascenzo, \& De Marco, 2019; Ting et al., 2016) dan mengarahkan mereka untuk menunjukkan perilaku pembelian. Penelitian juga menunjukkan bahwa jika kualitas informasi otentik, tepat, akurat, dan dapat dimengerti (Olivier \& Terblanche, 2016; Osei-Frimpong, 2019) secara real-time membantu pelanggan dalam proses pengambilan keputusan (Atulkar \& Kesari, 2018). Jumlah informasi yang relevan dan berguna yang tepat yang diberikan oleh aplikasi online akan meningkatkan kepercayaan pada pelanggan (Atulkar \& Kesari, 2018) dan menghasilkan pengaruh positif terhadap niat pembelian. Oleh karena itu, penelitian ini menyajikan hipotesis berikut.

H6. Informasi yang dirasakan memiliki hubungan positif yang signifikan dengan konversi pelanggan.

\section{Manajemen Hubungan Pelanggan}


Manajemen hubungan pelanggan (CRM) adalah fasilitas yang disediakan oleh aplikasi pemesanan makanan, yang menawarkan pelanggan untuk membuat profil pengguna pribadi mereka yang disesuaikan di aplikasi tertentu (Osei-Frimpong, 2019; Ting et al., 2016) dan mengakses akun mereka dengan aman melalui username dan kata sandi yang aman (Yang et al., 2015). Hal ini menciptakan hubungan positif dengan pelanggan dan dianggap sebagai salah satu alasan paling penting bagi pelanggan untuk menggunakan aplikasi pemesanan makanan yang mengarah pada konversi pelanggan (Atulkar \& Kesari, 2017; Taylor \& Levin, 2014). Penelitian sebelumnya mengidentifikasi manajemen hubungan pelanggan sebagai salah satu faktor konseptual penting (Yang et al., 2015) berdasarkan wawancara dan diskusi kelompok yang membantu dalam menjaga hubungan dengan pelanggan dan mempertahankannya untuk jangka panjang (A. Kumar \& Anjaly, 2017; R. Singh, 2019). Shankar \& Datta (2018) juga menunjukkan bahwa aplikasi pemesanan makanan memungkinkan pengguna untuk menyimpan alamat, hidangan favorit, dan restoran mereka di aplikasi atau situs web tertentu. Hal ini juga menawarkan layanan untuk berbagi umpan balik mereka tentang makanan dan layanan yang dikonsumsi melalui aplikasi (Sane \& Chopra, 2014). Penelitian sebelumnya juga mengamati bahwa aplikasi pemesanan makanan memfasilitasi pelanggan untuk memilih gateway pembayaran otomatis dan aman untuk menempatkan pesanan mereka (Ting et al., 2016; Ünal et al., 2011). Oleh karena itu, semua fasilitas ini melalui CRM membantu pelanggan dalam memutuskan makanan dan restoran dalam menempatkan pesanan di masa depan. Oleh karena itu, penelitian ini menyajikan hipotesis berikut.

H7. Manajemen hubungan pelanggan memiliki hubungan positif yang signifikan dengan konversi pelanggan.

\section{Sistem Manajemen Pesanan}

Menurut Ünal et al. (2011), sistem manajemen pesanan (OMS) adalah fasilitas yang ditawarkan kepada pelanggan untuk menggunakan layanan yang mudah sambil memesan makanan dari aplikasi pemesanan makanan. Penelitian sebelumnya menyarankan agar fasilitas OMS ini membuat seluruh proses pemesanan lancar dan otomatis, mulai dari penempatan pesanan hingga pengiriman pesanan (Madan \& Yadav, 2018; Shankar \& Datta, 2018; Ting et al., 2016). Para peneliti mengamati bahwa fasilitas ini telah digunakan secara khusus oleh pelanggan muda (Sane \& Chopra, 2014). Fasilitas OMS ini telah digunakan sebagai atribut utama untuk memilih aplikasi pemesanan makanan oleh pelanggan (Malik et al., 2017; Qin, Kim, \& Tan, 2018) secara teratur karena berdampak pada konversi pelanggan. Setelah melakukan pesanan oleh pelanggan melalui aplikasi pemesanan makanan (A. Kumar \& Anjaly, 2017), mereka menerima notifikasi dan juga mendapatkan pemberitahuan SMS 
yang memberi mereka aksesibilitas untuk melacak pesanan yang ditempatkan secara elektronik (D. G. Taylor \& Levin, 2014). Dengan demikian, pelanggan tidak harus menyimpan catatan pesanan yang ditempatkan melainkan pada aplikasi tersebut (N. Singh et al., 2020). Oleh karena itu, penelitian ini menyajikan hipotesis berikut.

H8. Sistem manajemen pesanan memiliki hubungan positif yang signifikan dengan konversi pelanggan.

\section{Konversi Pelanggan}

Menurut Kapoor \& Vij (2018), konversi berarti ketika ada pelanggan yang telah menerima dan menggunakan aplikasi pemesanan makanan tertentu untuk menempatkan pesanan dari ponsel pintar mereka. Penelitian sebelumnya menunjukkan bahwa aplikasi pemesanan makanan menawarkan manfaat moneter dalam bentuk insentif (Olivier \& Terblanche, 2016; D. G. Taylor \& Levin, 2014), kupon diskon, penawaran promosi, diskon loyalitas, hadiah cash back, kupon rujukan, dan poin loyalitas (Ting et al., 2016; Ünal et al., 2011). Manfaat ini memotivasi pelanggan untuk menunjukkan perilaku pembelian dari teknologi aplikasi seluler daripada membeli dari toko ritel offline yang menunjukkan konversi pelanggan ( $N$. Singh et al., 2020). Penelitian sebelumnya juga mengamati bahwa pelanggan sangat sensitif terhadap harga, dan oleh karena itu semua jenis manfaat moneter ini memotivasi mereka untuk mengembangkan sikap untuk menggunakan aplikasi pemesanan makanan (Malik et al., 2017; Qin et al., 2018). Akibatnya, peneliti juga menyarankan agar pelanggan dipengaruhi dan dikonversi oleh berbagai aspek psikologis (Shankar \& Datta, 2018; Shankar \& Kumari, 2016) dan atribut teknologi (N. Singh et al., 2020; Wang et al., 2019) seperti teknologi aplikasi seluler sambil memilih aplikasi pemesanan makanan. Oleh karena itu, persepsi kemudahan penggunaan, persepsi kegunaan, insentif, persepsi harga, desain visual, persepsi informasi, manajemen hubungan pelanggan, dan sistem manajemen pesanan sebagai bagian dari atribut psikologis dan teknologi mempengaruhi konversi pelanggan.

\section{METODE}

\section{Pengukuran Konstruk}

Semua item penelitian untuk konstruksi independen dan terikat diambil dari tinjauan literatur yang ada. Sebuah studi percontohan dilakukan untuk penyempurnaan dan untuk meningkatkan validitas eksternal dan validitas internal item penelitian. Akhirnya, satu set 29 pertanyaan (dari 35 item) telah diidentifikasi oleh peneliti dan digunakan untuk pengembangan kuesioner akhir. Kuesioner terdiri dari dua bagian, pertama karakteristik demografis responden, dan kedua pertanyaan yang berkaitan dengan konstruksi yang diidentifikasi. Semua item dari setiap konstruksi diukur dalam skala Likert lima titik, mulai dari sangat tidak setuju = 1 untuk sangat setuju $=5$. 
Variabel kemudahan penggunaan terdiri dari 3 pertanyaan dengan reliabilitas sebesar 0,83. Variabel kegunaan terdiri dari 3 pertanyaan dengan reliabilitas sebesar 0,78 . Variabel insentif terdiri dari 4 pertanyaan dengan reliabilitas sebesar 0,78 . Variabel harga terdiri dari 2 pertanyaan dengan reliabilitas sebesar 0,83 . Variabel desain visual terdiri dari 3 pertanyaan dengan reliabilitas 0,77 . Variabel persepsi informasi terdiri dari 3 pertanyaan dengan reliabilitas 0,84 . Variabel manajemen hubungan pelanggan terdiri dari 4 pertanyaan dengan reliabilitas sebesar 0,90. Variabel sistem manajemen pesanan terdiri dari 4 pertanyaan dengan reliabilitas sebesar 0,86 . Terakhir, variabel konversi pelanggan terdiri dari 3 pertanyaan dengan reliabilitas sebesar 0,82. Pertanyaan-pertanyaan pada kuesioner tersebut diadaptasi dari Atulkar \& Singh (2021).

\section{Proses Pengumpulan Data}

Metode kuesioner terstruktur digunakan untuk proses pengumpulan data dari responden yaitu mahasiswa yang kami anggap sudah mengenal teknologi aplikasi seluler. Semua responden terdapat di Jakarta kelompok usia antara 18 dan 35 tahun, untuk mendapatkan lebih banyak representasi masyarakat. Semua responden dipandu sebelum mengisi kuesioner untuk mendapatkan tanggapan asli untuk aplikasi pemesanan makanan menggunakan metode convenience sampling pada bulan September - Oktober 2021 selama akhir pekan. Oleh karena itu, jumlah total 374 kuesioner yang dapat digunakan digunakan oleh para peneliti untuk analisis data empiris dari 505 kuesioner terdistribusi (Tabel 1).

Tabel 1. Karakteristik Demografik

\begin{tabular}{|c|c|c|c|}
\hline Variabel & Kategori & Frekuensi & $\begin{array}{c}\text { Persentase } \\
\text { (\%) }\end{array}$ \\
\hline \multirow{2}{*}{ Jenis Kelamin } & Laki-Laki & 210 & 56 \\
\hline & Perempuan & 164 & 44 \\
\hline \multirow[t]{4}{*}{ Umur } & $18-20$ & 90 & 24 \\
\hline & $21-25$ & 134 & 36 \\
\hline & $26-30$ & 104 & 28 \\
\hline & $31-35$ & 46 & 12 \\
\hline \multirow[t]{4}{*}{ Pendidikan } & SMA/SMK & 83 & 22 \\
\hline & S-1 & 134 & 36 \\
\hline & $\mathrm{S}-2$ & 112 & 30 \\
\hline & Lainnya & 45 & 12 \\
\hline \multirow[t]{4}{*}{ Pekerjaan } & Mahasiswa & 166 & 44 \\
\hline & Karyawan & 114 & 30 \\
\hline & Wiraswasta & 40 & 11 \\
\hline & Lainnya & 54 & 14 \\
\hline \multirow{3}{*}{$\begin{array}{c}\text { Frekuensi } \\
\text { menggunakan } \\
\text { aplikasi }\end{array}$} & Sehari sekali & 96 & 26 \\
\hline & $\begin{array}{l}\text { Seminggu } \\
\text { sekali }\end{array}$ & 121 & 32 \\
\hline & $\begin{array}{c}\text { Sebulan } \\
\text { sekali }\end{array}$ & 157 & 42 \\
\hline \multirow{4}{*}{$\begin{array}{l}\text { Penggunaan } \\
\text { aplikasi } \\
\text { pemesanan } \\
\text { makanan } \\
\text { sejak }\end{array}$} & $<1$ tahun & 112 & 30 \\
\hline & 1-2 tahun & 165 & 44 \\
\hline & 2-3 tahun & 71 & 19 \\
\hline & $>3$ tahun & 26 & 7 \\
\hline
\end{tabular}

\section{Analisis Data dan Hasil}

Analisis pemodelan struktural (structural equation modelling atau SEM) (Bagozzi \& Edwards, 1998; Davison, Hinkley, \& Young, 2003) melalui metode partial least square (PLS) menggunakan perangkat lunak statistik SmartPLS 3.0 digunakan dalam penelitian ini. Perangkat lunak ini menghitung nilai validitas dan keandalan konstruksi. Metode PLS-SEM dianggap sebagai metode yang tepat (Hair, Ringle, \& Sarstedt, 2011) karena dianggap cocok untuk proses analisis data parametrik dan nonparametrik. Penelitian ini juga memperkirakan nilai signifikansi statistik dari loading factor dan 
koefisien jalur (Davison et al., 2003; Henseler, Ringle, \& Sarstedt, 2015) dengan menggunakan prosedur bootstrap non-parametrik sebagaimana dilakukan oleh (Baskoro, Al Sukri, \& Susilo, 2021). Oleh karena itu, koefisien jalur signifikan jika nilai $\mathrm{t}$ lebih tinggi dari 1,96 dengan tingkat signifikansi 5\% baru dianggap hipotesis telah diterima.

\section{Validitas dan Reliabilitas}

Studi mengukur keandalan konstruks melalui nilai-nilai Composite reliability (CR) and Cronbach's alpha $(\mathrm{C} \alpha)$ yang harus sama dan melampaui standar minimum 0,70 (Joseph F. Hair, Sarstedt, \& Ringle, 2019) dalam kedua kasus tersebut. Temuan ini mengamati bahwa nilai-nilai untuk Cronbach's alpha berkisar dari 0,77 to 0,90 , dan untuk $C R$ nilainya berkisar antara 0,72 dan 0,82 .

Demikian pula untuk mengukur validitas konstruksi, para peneliti mengamati nilai-nilai validitas konvergen (Fornell \& Larcker, 1981) melalui nilai factor loading dan AVE yang diharapkan lebih tinggi dari 0,50 (Bagozzi \& Edwards, 1998). Nilai-nilai yang dihasilkan dari factor loading (0.56-0.78) dan nilai AVE (average variance extracted) (0.59-0.78) melampaui standar minimum 0,50 . Studi juga mengamati nilai validitas diskriminan (Fornell \& Larcker, 1981) dengan mengidentifikasi interkorelasi antara konstruks yang dilihat dari nilai akar kuadrat AVE. Oleh karena itu, penelitian menyimpulkan bahwa model pengukuran menunjukkan keandalan dan validitas yang cukup sebagaimana pada Tabel 2 dan 3.

Tabel 2. Analisis Reliabilitas dan Validitas

\begin{tabular}{|c|c|c|c|c|c|}
\hline Variabel & Konstruk & Loading & AVE & CR & $\mathrm{C} \alpha$ \\
\hline $\begin{array}{c}\text { Persepsi } \\
\text { Kemudahan } \\
\text { Penggunaan }\end{array}$ & $\begin{array}{l}\text { PKP1 } \\
\text { PKP2 } \\
\text { PKP3 }\end{array}$ & $\begin{array}{l}0,67 \\
0,73 \\
0,68\end{array}$ & 0,69 & 0,75 & 0,83 \\
\hline $\begin{array}{l}\text { Persepsi } \\
\text { Kegunaan }\end{array}$ & $\begin{array}{l}\text { PK1 } \\
\text { PK2 } \\
\text { PK3 } \\
\end{array}$ & $\begin{array}{l}0,59 \\
0,74 \\
0,62 \\
\end{array}$ & 0,67 & 0,72 & 0,78 \\
\hline $\begin{array}{l}\text { Persepsi } \\
\text { Insentif }\end{array}$ & $\begin{array}{l}\mathrm{PI} 1 \\
\mathrm{PI} 2 \\
\mathrm{PI3} \\
\mathrm{PI} 4\end{array}$ & $\begin{array}{l}0,75 \\
0,63 \\
0,75 \\
0,58\end{array}$ & 0,76 & 0,74 & 0,78 \\
\hline $\begin{array}{c}\text { Persepsi } \\
\text { Harga }\end{array}$ & $\begin{array}{l}\mathrm{PH} 1 \\
\mathrm{PH} 2\end{array}$ & $\begin{array}{l}0,61 \\
0,78\end{array}$ & 0,78 & 0,76 & 0,83 \\
\hline Desain Visual & $\begin{array}{l}\text { DV1 } \\
\text { DV2 } \\
\text { DV3 }\end{array}$ & $\begin{array}{l}0,72 \\
0,56 \\
0,78 \\
\end{array}$ & 0,59 & 0,79 & 0,77 \\
\hline $\begin{array}{l}\text { Persepsi } \\
\text { Informasi }\end{array}$ & $\begin{array}{l}\text { PIN1 } \\
\text { PIN2 } \\
\text { PIN3 }\end{array}$ & $\begin{array}{l}0,71 \\
0,57 \\
0,63 \\
\end{array}$ & 0,70 & 0,78 & 0,84 \\
\hline $\begin{array}{c}\text { Manajemen } \\
\text { Hubungan } \\
\text { Pelanggan }\end{array}$ & $\begin{array}{l}\text { CRM1 } \\
\text { CRM2 } \\
\text { CRM3 } \\
\text { CRM4 }\end{array}$ & $\begin{array}{l}0,61 \\
0,78 \\
0,69 \\
0,77\end{array}$ & 0,74 & 0,82 & 0,86 \\
\hline $\begin{array}{c}\text { Sistem } \\
\text { Manajemen } \\
\text { Pesanan }\end{array}$ & $\begin{array}{l}\text { OMS1 } \\
\text { OMS2 } \\
\text { OMS3 } \\
\text { OMS4 }\end{array}$ & $\begin{array}{l}0,62 \\
0,75 \\
0,77 \\
0,67\end{array}$ & 0,77 & 0,78 & 0,86 \\
\hline $\begin{array}{c}\text { Konversi } \\
\text { Pelanggan }\end{array}$ & $\begin{array}{l}\mathrm{KP} 1 \\
\mathrm{KP} 2 \\
\mathrm{KP} 3\end{array}$ & $\begin{array}{l}0,75 \\
0,66 \\
0,72 \\
\end{array}$ & 0,73 & 0,78 & 0,82 \\
\hline
\end{tabular}

\section{Structural Model Assessment}

Untuk menilai keseluruhan model fit (Chin, Marcelin, \& Newsted, 2003) studi mengidentifikasi goodness of fit (GoF) yang diusulkan oleh (Tenenhaus, Vinzi, Chatelin, \& Lauro, 2005) dimana rata-rata AVE dan $\mathrm{R}^{2}$ ratarata (untuk konstruks endogen) telah digunakan untuk perhitungan Nilai GoF. Rumus GoF yang disarankan oleh Wetzels et al. (2009) adalah:

$$
G o F=\sqrt{\overline{A V E} \times R^{2}}
$$

Peneliti menyarankan nilai minimum untuk menilai GoF adalah 0,10 (kecil), 0,25 (sedang), dan 0,36 (besar) (Wetzels et al., 2009). Kemudian nilai GoF yang dihasilkan dari model 
penelitian ini sebesar 0,57 dimana nilai AVE sebesar 0,72 dan nilai $R^{2}$ sebesar 0,46 yang mengindikasikan model fit yang baik dalam penelitian ini.

Penelitian ini juga menguji toleransi dan variance inflation factor (VIF) menggunakan perangkat lunak IBM SPSS 20 sebagaimana Tabel 4 dan menemukan nilai VIF tidak lebih dari 5 (nilai variabel $<2,731$ ) dan nilai toleransi $>0,20$ (Hair et al., 2014). Diketahui bahwa berdasarkan hasil tersebut menunjukkan tidak terjadi multikolinieritas antara variabel.

Tabel 3. Korelasi Variabel Laten

\begin{tabular}{|c|c|c|c|c|c|c|c|c|c|}
\hline Konstruk & PKP & PK & PI & PH & DV & PIN & CRM & OMS & KP \\
\hline PKP & $\mathbf{0 , 8 3}$ & & & & & & & & \\
\hline PK & 0,79 & $\mathbf{0 , 8 1}$ & & & & & & & \\
\hline PI & 0,80 & 0,70 & $\mathbf{0 , 8 7}$ & & & & & & \\
\hline PH & 0,82 & 0,70 & 0,70 & $\mathbf{0 , 8 8}$ & & & & & \\
\hline DV & 0,79 & 0,69 & 0,66 & 0,67 & $\mathbf{0 , 8 3}$ & & & & \\
\hline PIN & 0,83 & 0,65 & 0,72 & 0,78 & 0,70 & $\mathbf{0 , 8 3}$ & & & \\
\hline CRM & 0,65 & 0,85 & 0,73 & 0,71 & 0,69 & 0,76 & $\mathbf{0 , 8 6}$ & & \\
\hline OMS & 0,83 & 0,68 & 0,69 & 0,76 & 0,70 & 0,81 & 0,76 & $\mathbf{0 , 8 7}$ & \\
\hline KP & 0,87 & 0,77 & 0,84 & 0,73 & 0,74 & 0,78 & 0,75 & 0,74 & $\mathbf{0 , 8 5}$ \\
\hline
\end{tabular}

Tabel 4. Pengaruh Langsung dan Koefisien Jalur

\begin{tabular}{|c|c|c|c|c|}
\hline Hipotesis & Beta & $\boldsymbol{p}$-value & VIF & Keterangan \\
\hline H1 & 0,227 & 0,023 & 1,043 & Signifikan \\
\hline H2 & 0,153 & 0,007 & 1,071 & Signifikan \\
\hline H3 & 0,167 & 0,017 & 1,281 & Signifikan \\
\hline H4 & 0,095 & 0,075 & 1,207 & $\begin{array}{c}\text { Tidak } \\
\text { Signifikan }\end{array}$ \\
\hline H5 & 0,181 & 0,089 & 2,531 & $\begin{array}{c}\text { Tidak } \\
\text { Signifikan }\end{array}$ \\
\hline H6 & 0,297 & 0,032 & 1,138 & Signifikan \\
\hline H7 & 0,142 & 0,019 & 1,245 & Signifikan \\
\hline H8 & 0,245 & 0,031 & 2,523 & Signifikan \\
\hline
\end{tabular}

\section{Pengaruh Utama dan Koefisien Jalur}

Prosedur bootstrap non-parametrik telah digunakan oleh peneliti pada SmartPLS 3.0 untuk menguji hipotesis yang diusulkan menggunakan nilai signifikansi dan koefisien jalur (Davison et al., 2003). Tabel 4 menunjukkan nilai koefisien jalur standar ( $\beta$ ), nilai $t$, dan tingkat signifikansi terkait untuk semua hubungan yang diusulkan. Dengan demikian, nilai yang dihasilkan menunjukkan bahwa persepsi kemudahan penggunaan, persepsi kegunaan, persepsi insentif, persepsi informasi, manajemen hubungan pelanggan, dan sistem manajemen pesanan memiliki pengaruh positif yang signifikan terhadap konversi pelanggan. Di sisi lain, desain visual dan persepsi harga menunjukkan pengaruh negatif yang tidak signifikan terhadap konversi pelanggan. Oleh karena itu, hipotesis $\mathrm{H} 1, \mathrm{H} 2$, $\mathrm{H} 3, \mathrm{H} 6, \mathrm{H} 7$ dan $\mathrm{H} 8$ diterima dan hipotesis $\mathrm{H} 4$ dan H5 ditolak (lihat Gambar 2).

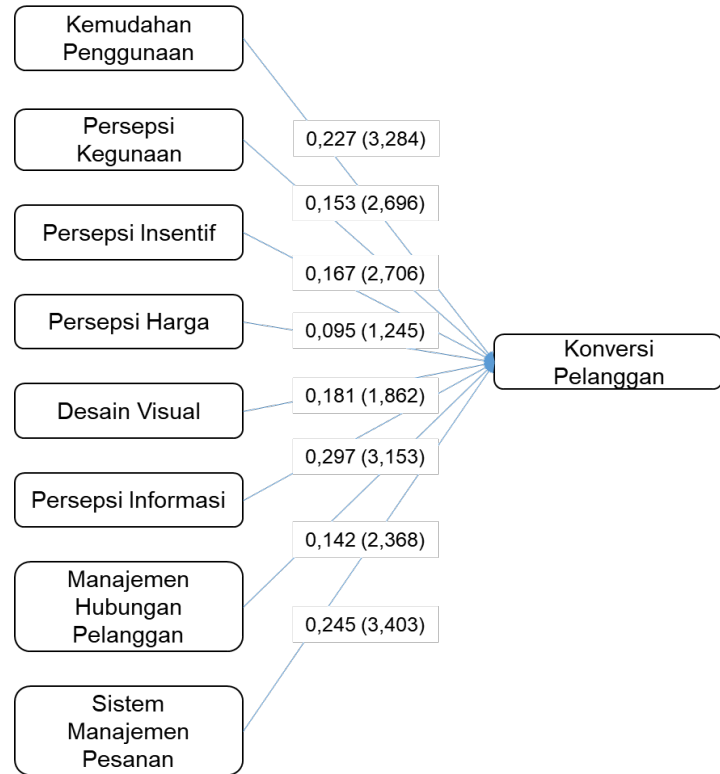

Gambar 2. Model Struktural

\section{PEMBAHASAN}

Studi ini mengeksplorasi bagaimana psikologis (persepsi kemudahan penggunaan, persepsi kegunaan, persepsi insentif dan persepsi harga) dan atribut teknologi (terdiri dari desain visual, persepsi informasi, manajemen hubungan pelanggan dan sistem manajemen pesanan) mempengaruhi sikap 
pelanggan untuk menggunakan aplikasi pemesanan makanan. Temuan menunjukkan bahwa pelanggan saat ini tidak perlu menunggu lama untuk mengakses layanan makanan yang diberikan oleh restoran dan menginginkan semua layanan bisa diakses dengan mudah. Studi juga menunjukkan bahwa teknologi aplikasi seluler harus mudah dimengerti dan mudah digunakan yang secara langsung atau tidak langsung mempengaruhi sikap pelanggan untuk menggunakan teknologi aplikasi seluler untuk memesan makanan dari penyedia layanan online. Oleh karena itu, hasil penelitian untuk hubungan antara kemudahan penggunaan yang dirasakan dan konversi pelanggan untuk menggunakan aplikasi pemesanan makanan menunjukkan efek positif yang signifikan dan mendukung penelitian sebelumnya (Kim et al., 2012; Shankar \& Datta, 2018).

Penelitian ini juga mengamati bahwa saat ini pelanggan muda lebih peduli tentang menggunakan aplikasi pemesanan makanan karena persepsi kegunaan dari layanan aplikasi seluler. Temuan menunjukkan bahwa dengan menggunakan teknologi pembayaran online, pelanggan dapat menyelesaikan tugas mereka dengan cepat, nyaman, dan merasa senang dengan aplikasi pemesanan makanan. Nilai yang dihasilkan untuk hubungan antara persepsi kegunaan dan konversi pelanggan untuk menggunakan aplikasi pemesanan makanan menunjukkan hubungan positif yang signifikan dan mendukung temuan penelitian sebelumnya (Kim et al., 2012; Madan \& Yadav, 2018; N.
Singh et al., 2020). Studi menunjukkan bahwa pelanggan saat ini lebih memilih aplikasi seluler untuk memesan makanan dari restoran terdekat yang memberikan layanan yang lebih nyaman dan bermanfaat dan juga memotivasi orang lain untuk menggunakan teknologi ini.

Temuan untuk hubungan antara persepsi insentif dan konversi pelanggan juga menunjukkan hasil positif yang signifikan. Studi mengamati bahwa insentif yang dirasakan dari memesan makanan secara online (A. Kumar \& Anjaly, 2017) memainkan peran penting pada konversi pelanggan untuk menggunakan aplikasi pemesanan makanan. Nilai yang dihasilkan menunjukkan bahwa sebagian besar pelanggan suka mendapatkan berbagai penawaran, skema, dan diskon yang tersedia di aplikasi sambil memesan makanan secara online. Penelitian ini mendukung studi penelitian sebelumnya (Olivier \& Terblanche, 2016; D. G. Taylor \& Levin, 2014; Ünal et al., 2011) dengan menunjukkan hasil positif yang signifikan. Pelanggan saat ini selalu terus mencari lebih banyak penawaran, diskon, cash back, point referral, loyalty points, dan lainlain dalam bentuk insentif dari aplikasi pemesanan makanan. Oleh karena itu, telah disarankan bahwa dengan menawarkan fasilitas ini menjadi mantra baru untuk mempengaruhi keputusan pembelian pelanggan dari aplikasi pemesanan makanan.

Sementara temuan penelitian untuk hubungan antara persepsi harga dan konversi pelanggan menunjukkan efek yang tidak signifikan dan mendukung temuan penelitian 
sebelumnya (Ünal et al., 2011). Telah diamati bahwa pelanggan selalu mencari harga yang menarik untuk pesanan mereka karena mereka suka menyimpan uang mereka dalam hal uang kembali dan diskon. Dengan demikian, dengan memanfaatkan barang dan jasa diskon oleh aplikasi pemesanan makanan online, pelanggan mengembangkan hubungan dengan pengguna lainnya sebagai hasil kolaborasi untuk pembelian di masa depan. Temuan menunjukkan bahwa kriteria pelanggan untuk memilih aplikasi pemesanan makanan tergantung pada penawaran yang disediakan oleh aplikasi pemesanan makanan, jika tidak, pelanggan mencari aplikasi baru dan menunjukkan perilaku beralih. Oleh karena itu, pelanggan didorong oleh berbagai penawaran dan diskon menarik yang tersedia di aplikasi pemesanan makanan.

Demikian pula, temuan penelitian untuk hubungan antara desain visual dan konversi pelanggan terhadap penggunaan aplikasi pemesanan makanan menunjukkan hasil yang tidak signifikan yang bertentangan dengan studi penelitian sebelumnya (Olivier \& Terblanche, 2016; R. Singh, 2019), sementara hal itu telah dianggap sebagai faktor pengaruh positif tertinggi pada konversi pelanggan. Temuan penelitian mengamati bahwa daya tarik visual menciptakan keterikatan pada pelanggan dan merasa mereka membingungkan dalam proses pengambilan keputusan dengan melihat gambar yang diposting. Oleh karena itu, ukuran, gambar, kombinasi warna dan desain visual dari makanan yang berbeda dan kompetitif pada aplikasi menciptakan motivasi pada pelanggan untuk beralih aplikasi dan menunjukkan pengaruh yang tidak signifikan pada pelanggan.

Hasil studi untuk hubungan antara informasi yang dirasakan dan konversi pelanggan untuk menggunakan aplikasi pemesanan makanan juga menunjukkan efek positif yang signifikan. Temuan menunjukkan bahwa aplikasi pemesanan makanan memberikan informasi terbaru terkait makanan, kualitas, kuantitas, dan harga kepada pelanggan melalui berbagai media promosi. Telah diamati bahwa aplikasi online mencakup gambar menu, ulasan di restoran dan terkait dengan kualitas makanan untuk menarik pelanggan baru. Selain itu aplikasi pemesanan makanan juga memiliki nomor kontak untuk mendukung pelanggan dengan berbagi informasi dan karena itu mendukung temuan penelitian sebelumnya (Elliot et al., 2013; Ting et al., 2016). Dengan demikian, pelanggan memerlukan semua jenis informasi yang relevan, terkini, dan otentik untuk membuat keputusan berdasarkan informasi sambil membuat pesanan dari aplikasi tertentu.

Demikian pula, temuan untuk membangun manajemen hubungan pelanggan juga menunjukkan pengaruh positif yang signifikan pada konversi pelanggan dan mendukung para peneliti sebelumnya (Shankar \& Datta, 2018; Ünal et al., 2011). Studi menunjukkan bahwa interaksi antara pelanggan dan penyedia layanan dilakukan melalui pembuatan profil pelanggan pada aplikasi tertentu yang 
memungkinkan mereka untuk mengamankan login dan menyesuaikan pesanan mereka dengan menggunakan aplikasi. Fasilitas ini sangat berguna dan memudahkan pelanggan untuk dengan mudah menyimpan alamat, restoran, umpan balik, dan juga menyesuaikan waktu penjemputan dan pengiriman mereka. Fasilitas makanan dan pembayaran online memicu pelanggan untuk menggunakan aplikasi pemesanan makanan. Dengan demikian, informasi yang dirasakan dari aplikasi pemesanan makanan dianggap sebagai anteseden penting dalam mengadopsi teknologi aplikasi seluler.

Bertentangan, dengan temuan yang dihasilkan dari temuan penelitian sebelumnya (Madan \& Yadav, 2018; Malik et al., 2017; Qin et al., 2018; Ting et al., 2016), penelitian ini menunjukkan pengaruh positif yang signifikan dari sistem manajemen pesanan pada konversi pelanggan. Temuan studi menunjukkan bahwa sistem manajemen pesanan mencakup semua langkah mulai dari pemilihan pesanan, penempatan pesanan dan konfirmasi pesanan yang ditetapkan melalui pengiriman pesanan email dan pesan di alamat email tertentu secara otomatis. Pelanggan tidak perlu menyimpan catatan pesanan yang ditempatkan dan menciptakan kegunaan aplikasi pemesanan makanan pada pelanggan. Hal ini memberikan rasa kelengkapan dan aksesibilitas yang mudah untuk melacak pesanan mereka ditempatkan secara elektronik dan memuaskan pelanggan sebagai hasil dari proses pemesanan. Fasilitas ini meningkatkan utilitas dan kemudahan aplikasi pemesanan makanan di benak pelanggan dan memicu mereka untuk memilih dan memesan melalui aplikasi pemesanan makanan hanya di masa depan juga.

\section{E. PENUTUP}

1. Kesimpulan

Akhirnya, penelitian ini menyimpulkan bahwa atribut psikologis seperti persepsi kemudahan penggunaan, persepsi kegunaan, dan persepsi insentif menunjukkan pengaruh positif yang signifikan pada konversi pelanggan. Sementara persepsi harga menunjukkan pengaruh negatif yang tidak signifikan. Demikian pula, atribut teknologi seperti persepsi informasi, manajemen hubungan pelanggan, dan sistem manajemen pesanan menunjukkan pengaruh positif yang signifikan.

Sementara, desain visual menunjukkan dampak negatif yang tidak signifikan pada konversi pelanggan ke aplikasi pemesanan makanan. Penelitian ini menunjukkan bahwa penyedia layanan perlu mengembangkan aplikasi pemesanan makanan dalam hal desain visual dan harus menawarkan harga yang menarik dalam skenario e-commerce yang kompetitif untuk menarik pelanggan baru dan menahan pelanggan mereka yang menguntungkan. Aplikasi pemesanan makanan juga perlu memberikan gambar dan informasi yang mengesankan, indah, tepat, akurat, dan relevan yang terkait dengan makanan dan fasilitas kepada pelanggan mereka. Penelitian ini menunjukkan bahwa manajemen hubungan 
pelanggan dan sistem manajemen pesanan harus terintegrasi dengan lancar dan dikelola karena pengguna lebih memilih aplikasi terutama dengan memahami fitur-fitur yang diberikan. Studi juga mengamati bahwa persepsi harga dan persepsi insentif dalam bentuk berbagai skema, diskon, dan penawaran mempengaruhi konversi pelanggan untuk menggunakan aplikasi pemesanan makanan dan memotivasi mereka untuk mempengaruhi orang lain untuk menggunakan aplikasi ini. Oleh karena itu, harapan pelanggan selalu terus berubah seiring waktu dan teknologi yang tersedia yang memotivasi pengguna untuk terus menawarkan teknologi baru dan memperbarui aplikasi mereka untuk menyediakan layanan yang lebih baik dalam bisnis aplikasi seluler yang paling cepat berkembang ini. Dengan demikian, layanan aplikasi seluler yang terencana dan dirancang dengan baik akan memfasilitasi penyedia layanan online untuk mengubah pelanggan baru menggunakan aplikasi pemesanan makanan dan juga mempertahankan yang sudah ada.

\section{Impilkasi Penelitian}

Dengan meningkatnya bisnis aplikasi seluler secara global, ada kebutuhan untuk mengenali setiap variabel, yang mengarah pada konversi pelanggan ke aplikasi pemesanan makanan. Studi ini mengeksplorasi pengaruh atribut psikologis dan teknologi dengan konversi pelanggan ke aplikasi pemesanan makanan. Hasil penelitian menunjukkan implikasi penelitian dengan menunjukkan bahwa teknologi aplikasi seluler membantu dalam menembus dan memperluas pasar konsumen dari perkotaan ke pedesaan dan mengambil bentuk besar dengan mentransfer dari satu masyarakat geografis ke masyarakat geografis lainnya. Atribut psikologis dan teknologi ini memainkan peran penting dalam konversi pelanggan, karena harapan pelanggan berubah dengan menyukai dan tidak menyukai aplikasi dengan waktu dan pergeseran teknologi. Penelitian ini membantu pengecer makanan untuk melakukan cashback dengan menawarkan fasilitas baru dan layanan bernilai tambah melalui aplikasi pemesanan makanan online. Studi juga mendukung pedagang kecil dan pedagang kaki lima untuk mulai menawarkan fasilitas ini dengan mengembangkan aplikasi menggunakan dan memfasilitasi semua variabel yang dibahas. Oleh karena itu, telah disarankan bahwa aplikasi pemesanan makanan berada pada tahap awal pengembangan dan memiliki potensi pertumbuhan yang baik di pasar Jakarta dan penelitian ini dapat memperkaya dan memberikan arahan kepada penyedia layanan aplikasi untuk memahami harapan pelanggan dan karenanya mereka dapat mempersiapkan strategi untuk menawarkan layanan yang lebih baik.

Studi juga menyajikan implikasi teoritis dengan mempertimbangkan pengaruh atribut psikologis dan teknologi pada konversi pelanggan. Berdasarkan temuan penelitian, penelitian ini menyajikan dua implikasi teoritis 
utama bagi akademisi dan peneliti yang dapat membantu dalam peningkatan model TAM. Pertama, penelitian ini berfokus pada aplikasi pemesanan makanan yang memiliki potensi pertumbuhan tinggi di pasar Jakarta karena sebagian besar pelanggan menunjukkan perilaku pembelian secara daring dan mereka menikmati seluruh proses pemesanan dengan mulus. Kedua, penelitian ini mengidentifikasi pengaruh signifikan negatif yang dirasakan harga dan desain visual pada konversi pelanggan. Oleh karena itu, pemahaman tentang variabel-variabel ini mengalihkan perhatian pelanggan untuk menggunakan aplikasi pemesanan makanan dapat digunakan sebagai dasar teoritis untuk mengintegrasikan temuan terbaru tentang pertumbuhan aplikasi pemesanan makanan online. Dengan meningkatkan fasilitas aplikasi ini memotivasi penyedia layanan, akademisi, dan peneliti untuk bekerja lebih banyak di atasnya dengan menambahkan beberapa variabel lain dan berkontribusi untuk memperkaya ulasan literatur.

3.

Keterbatasan

\section{dan Penelitian Selanjutnya}

Terlepas dari studi yang terencana dengan baik, selalu ada beberapa keterbatasan dan ruang lingkup perbaikan. Pertama, penelitian ini berfokus di Jakarta tengah dan kelompok usia pelanggan antara 18 dan 35 tahun, terutama calon mahasiswa yang akan menjadi mahasiswa. Kekuatan dan persyaratan pembelian juga sangat berbeda dari pelanggan yang tinggal bersama keluarga. Penelitian ini tidak dapat digeneralisasikan untuk seluruh masyarakat. Dengan demikian, para peneliti masa depan dapat fokus pada variabel-variabel ini untuk membuat lebih banyak generalisasi dengan melibatkan lebih banyak representasi masyarakat dari berbagai daerah dan dari pelanggan demografi yang berbeda. Studi ini hanya berfokus pada sikap pelanggan untuk menggunakan aplikasi pemesanan makanan saja dan karenanya peneliti masa depan dapat fokus pada aplikasi ritel online lainnya yang memfasilitasi pelanggan untuk memesan barang dan jasa. Ada beberapa atribut lagi yang mempengaruhi konversi pelanggan untuk menggunakan aplikasi pemesanan makanan online, terutama pendekatan karakter terhadap aplikasi online yang perlu dipertimbangkan oleh para peneliti masa depan. Pilihan pembayaran yang lancar mungkin merupakan faktor teknis lain untuk memilih dan konversi pengguna yang tetap ditemukan dalam penelitian ini. Oleh karena itu, penelitian ini akan membantu akademisi dan peneliti masa depan untuk fokus pada sikap pelanggan untuk menggunakan teknologi aplikasi seluler untuk mendapatkan hasil yang bermanfaat dan produktif.

\section{DAFTAR PUSTAKA}

Apanasevic, T., Markendahl, J., \& Arvidsson, N. (2016). Stakeholders' expectations of mobile payment in retail: lessons from Sweden. International Journal of Bank Marketing, 34(1), 37-61. https://doi.org/10.1108/IJBM-06-20140064 
Arvidsson, N. (2014). Consumer attitudes on mobile payment services - results from a proof of concept test. International Journal of Bank Marketing, 32(2), 150170. https://doi.org/10.1108/IJBM-05-

$$
\text { 2013-0048 }
$$

Atulkar, S. (2019). Measuring the Effects of Retail Functional Strategies on the Growth of Organized Retail Environments. Journal of Marketing Vistas, 9(1), 58-68.

Atulkar, S. (2020). Brand trust and brand loyalty in mall shoppers. Marketing Intelligence and Planning, 38(5), 559-572. https://doi.org/10.1108/MIP-02-20190095

Atulkar, S., \& Kesari, B. (2017). Impulse Buying: A Consumer Trait Prospective in Context of Central India. Global Business Review, 19(2), 477-493.

https://doi.org/10.1177/09721509177135 46

Atulkar, S., \& Kesari, B. (2018). Role of consumer traits and situational factors on impulse buying: does gender matter? International Journal of Retail and Distribution Management, 46(4), 386-405. https://doi.org/10.1108/IJRDM-12-20160239

Atulkar, S., \& Singh, A. K. (2021). Role of psychological and technological attributes on customer conversion to use food ordering apps. International Journal of Retail and Distribution Management, 49(10), 1430-1446.

https://doi.org/10.1108/IJRDM-09-20200349

Bagozzi, R. P., \& Edwards, J. R. (1998). A general approach for representing constructs in organizational research. Organizational

Research Methods, 1(1), 45-87.

https://doi.org/10.1177/10944281980010 0104

Baskoro, B. D., Al Sukri, S., \& Susilo, D. E. (2021). Hubungan antara Nilai Kerja, Berbagi Pengetahuan, dan Kinerja Kreatif: Studi pada Pekerja Konstruksi di Jakarta. POINT: Jurnal Ekonomi Dan Manajemen, 3(1), 1122.

https://doi.org/10.46918/point.v3i1.881

Chen, L. Da. (2008). A model of consumer acceptance of mobile payment.
International Journal of Mobile

Communications, 6(1), 32-52.

https://doi.org/10.1504/IJMC.2008.01599

7

Chin, W. W., Marcelin, B. L., \& Newsted, P. R.

(2003). A partial least squares latent variable modeling approach for measuring interaction effects: Results from a Monte Carlo simulation study and an electronicmail emotion/adoption study. Information Systems Research, 14(2).

https://doi.org/10.1287/isre.14.2.189.160

18

Davis, F. D. (1989). Perceived usefulness, perceived ease of use, and user acceptance of information technology. MIS Quarterly, 13(3), 319-340. https://doi.org/10.2307/249008

Davis, F. D., Bagozzi, R. P., \& Warshaw, P. R.

(1992). Extrinsic and Intrinsic Motivation to Use Computers in the Workplace. Journal of Applied Social Psychology, 22(14), 1111-1132.

https://doi.org/10.1111/j.15591816.1992.tb00945.x

Davison, A. C., Hinkley, D. V., \& Young, G. A. (2003). Recent Developments in Bootstrap Methodology. Statistical Science, 18(2), 141-157.

https://doi.org/10.1214/ss/1063994969

Elliot, S., Li, G., \& Choi, C. (2013). Understanding service quality in a virtual travel community environment. Journal of Business Research, 66(8), 1153-1160. https://doi.org/10.1016/j.jbusres.2012.03. 011

Fornell, C., \& Larcker, D. F. (1981). Structural Equation Models with Unobservable

Variables and Measurement Error: Algebra and Statistics. Journal of Marketing Research, 18(3), 382. https://doi.org/10.2307/3150980

Hagberg, J., Sundstrom, M., \& Egels-Zandén, N. (2016). The digitalization of retailing: an exploratory framework. International Journal of Retail and Distribution Management, 44(7), 694-712. https://doi.org/10.1108/IJRDM-09-20150140

Hair, Joe F., Ringle, C. M., \& Sarstedt, M. (2011). PLS-SEM: Indeed a silver bullet. Journal of 
Marketing Theory and Practice, 19(2), 139-152.

https://doi.org/10.2753/MTP10696679190202

Hair, Joe F., Sarstedt, M., Hopkins, L., \& Kuppelwieser, V. G. (2014). Partial least squares structural equation modeling (PLS-SEM): An emerging tool in business research. European Business Review, 26(2), 106-121.

https://doi.org/10.1108/EBR-10-20130128

Hair, Joseph F., Sarstedt, M., \& Ringle, C. M.

(2019). Rethinking some of the rethinking of partial least squares. European Journal of Marketing, 53(4), 566-584.

https://doi.org/10.1108/EJM-10-20180665

Harwani, Y., \& Fauziyah, F. (2020). Keputusan Pembelian Konsumen Gerai Makanan Cepat Saji Ditinjau dari Kualitas Produk, Persepsi Harga dan Iklan. Business Economic, Communication, and Social Sciences (BECOSS) Journal, 2(3), 285-291. https://doi.org/10.21512/becossjournal.v $2 i 3.6659$

Henseler, J., Ringle, C. M., \& Sarstedt, M.

(2015). A new criterion for assessing discriminant validity in variance-based structural equation modeling. Journal of the Academy of Marketing Science, 43(1), 115-135. https://doi.org/10.1007/s11747014-0403-8

Ho, J. C., Wu, C. G., Lee, C. S., \& Pham, T. T. T. (2020). Factors affecting the behavioral intention to adopt mobile banking: An international comparison. Technology in Society, 63(August), 101360.

https://doi.org/10.1016/j.techsoc.2020.10 1360

Iyer, G. R., Blut, M., Xiao, S. H., \& Grewal, D.

(2020). Impulse buying: a meta-analytic review. Journal of the Academy of Marketing Science, 48(3), 384-404. https://doi.org/10.1007/s11747-01900670-w

Johnson, V. L., Kiser, A., Washington, R., \& Torres, R. (2018). Limitations to the rapid adoption of M-payment services:

Understanding the impact of privacy risk on M-Payment services. Computers in
Human Behavior, 79, 111-122.

https://doi.org/10.1016/j.chb.2017.10.035

Kapoor, A. P., \& Vij, M. (2018). Technology at the dinner table: Ordering food online through mobile apps. Journal of Retailing and Consumer Services, 43(March), 342351.

https://doi.org/10.1016/j.jretconser.2018. 04.001

Katadata. (2021). Daftar Negara Pengguna Smartphone Terbanyak, Indonesia Urutan Berapa? Retrieved from

https://databoks.katadata.co.id/datapubli sh/2021/07/01/daftar-negara-penggunasmartphone-terbanyak-indonesia-urutanberapa\#: :text=Kemudian\%2C Indonesia menempati posisi keempat,\%2C6\%25 dari total populasi.

Kim, H. W., Xu, Y., \& Gupta, S. (2012). Which is more important in Internet shopping, perceived price or trust? Electronic Commerce Research and Applications, 11(3), 241-252.

https://doi.org/10.1016/j.elerap.2011.06. 003

Kumar, A., \& Anjaly, B. (2017). How to measure post-purchase customer experience in online retailing? A scale development study. International Journal of Retail and Distribution Management, 45(12), 12771297. https://doi.org/10.1108/IJRDM-012017-0002

Kumar, Ashish, Dhingra, S., Batra, V., \& Purohit, H. (2020). A Framework of Mobile Banking Adoption in India. Journal of Open Innovation: Technology, Market, and Complexity, 6(2), 1-17.

https://doi.org/10.3390/JOITMC6020040

Liu, Y., \& Dewitte, S. (2021). A replication study of the credit card effect on spending behavior and an extension to mobile payments. Journal of Retailing and Consumer Services, 60(August 2020), 102472.

https://doi.org/10.1016/j.jretconser.2021. 102472

Madan, K., \& Yadav, R. (2018). Understanding and predicting antecedents of mobile shopping adoption: A developing country perspective. Asia Pacific Journal of Marketing and Logistics, 30(1), 139-162. 
https://doi.org/10.1108/APJML-02-20170023

Malik, A., Suresh, S., \& Sharma, S. (2017). Factors influencing consumers' attitude towards adoption and continuous use of mobile applications: A conceptual model. Procedia Computer Science, 122, 106-113. https://doi.org/10.1016/j.procs.2017.11.3 48

Marriott, H. R., \& Williams, M. D. (2018). Exploring consumers perceived risk and trust for mobile shopping: A theoretical framework and empirical study. Journal of Retailing and Consumer Services, 42(February), 133-146.

https://doi.org/10.1016/j.jretconser.2018. 01.017

Medcom. (2021). Bisnis Layanan Pesan Antar Makanan Online Meningkat Selama Pandemi. Retrieved from

https://www.medcom.id/ekonomi/bisnis/ 8kolVnWK-bisnis-layanan-pesan-antarmakanan-online-meningkat-selamapandemi

Olivier, X., \& Terblanche, N. S. (2016). An investigation into the antecedents and outcomes of the m-shopping experience. The Business and Management Review, 7(5), 263-287.

Osei-Frimpong, K. (2019). Understanding consumer motivations in online social brand engagement participation: Implications for retailers. International Journal of Retail and Distribution Management, 47(5), 511-529. https://doi.org/10.1108/IJRDM-08-20180151

Qin, L., Kim, Y., \& Tan, X. (2018). Understanding the Intention of Using Mobile Social Networking Apps Across Cultures. International Journal of Human-Computer Interaction, 34(12), 1183-1193.

https://doi.org/10.1080/10447318.2018.1 428262

Reimers, V., \& Clulow, V. (2009). Retail centres: It's time to make them convenient. International Journal of Retail \& Distribution Management, 37(7), 541-562. https://doi.org/10.1108/09590550910964 594

Sane, V., \& Chopra, K. (2014). Analytical Study of Shopping Motives of Young Customers for Selected Product Categories with

Reference to Organized Retailing in Select Metropolitan Select Cities of India.

Procedia - Social and Behavioral Sciences, 133, 160-168.

https://doi.org/10.1016/j.sbspro.2014.04. 181

Savastano, M., Bellini, F., D’Ascenzo, F., \& De Marco, M. (2019). Technology adoption for the integration of online-offline purchasing: Omnichannel strategies in the retail environment. International Journal of Retail and Distribution Management, 47(5), 474-492.

https://doi.org/10.1108/JJRDM-12-20180270

Shankar, A., \& Datta, B. (2018). Factors Affecting Mobile Payment Adoption Intention: An Indian Perspective. Global Business Review, 19(3_suppl), S72-S89. https://doi.org/10.1177/09721509187578 70

Shankar, A., \& Kumari, P. (2016). Factors affecting mobile banking adoption behavior in India. Journal of Internet Banking and Commerce, 21(1), 1-24.

Singh, N., Sinha, N., \& Liébana-Cabanillas, F. J.

(2020). Determining factors in the adoption and recommendation of mobile wallet services in India: Analysis of the effect of innovativeness, stress to use and social influence. International Journal of Information Management, 50(May 2019), 191-205.

https://doi.org/10.1016/j.ijinfomgt.2019.0 5.022

Singh, R. (2019). Why do online grocery shoppers switch or stay? An exploratory analysis of consumers' response to online grocery shopping experience. International Journal of Retail and Distribution Management, 47(12), 13001317. https://doi.org/10.1108/IJRDM-102018-0224

Taylor, D. G., \& Levin, M. (2014). Predicting mobile app usage for purchasing and information-sharing. International Journal of Retail and Distribution Management, 42(8), 759-774.

https://doi.org/10.1108/JJRDM-11-2012- 


\section{8}

Taylor, E. (2016). Mobile payment technologies in retail: a review of potential benefits and risks. International Journal of Retail and Distribution Management, 44(2), 159-177. https://doi.org/10.1108/IJRDM-05-20150065

Teller, C., Brusset, X., \& Kotzab, H. (2019). Physical and digital market places - where marketing meets operations. International Journal of Retail and Distribution Management, 47(12), 1225-1231. https://doi.org/10.1108/IJRDM-12-2019299

Tenenhaus, M., Vinzi, V. E., Chatelin, Y. M., \& Lauro, C. (2005). PLS path modeling. Computational Statistics and Data Analysis, 48(1), 159-205. https://doi.org/10.1016/j.csda.2004.03.00 5

Ting, H., Yacob, Y., Liew, L., \& Lau, W. M. (2016). Intention to Use Mobile Payment System: A Case of Developing Market by Ethnicity. Procedia - Social and Behavioral Sciences, 224(August 2015), 368-375. https://doi.org/10.1016/j.sbspro.2016.05. 390

Ünal, S., Erciş, A., \& Keser, E. (2011). Attitudes towards mobile advertising - A research to determine the differences between the attitudes of youth and adults. Procedia Social and Behavioral Sciences, 24, 361377.

https://doi.org/10.1016/j.sbspro.2011.09.
067

Wang, Y. S., Tseng, T. H., Wang, W. T., Shih, Y. W., \& Chan, P. Y. (2019). Developing and validating a mobile catering app success model. International Journal of Hospitality Management, 77(December 2016), 19-30. https://doi.org/10.1016/j.ijhm.2018.06.00 2

Wetzels, M., Odekerken-Schroder, G., \& Oppen, C. Van. (2009). Using PLS path modeling for assessing hierarchical construct models: guidelines and empirical illustration. MIS Quarterly, 33(1), 177-195. Yang, Y., Liu, Y., Li, H., \& Yu, B. (2015). Understanding perceived risks in mobile payment acceptance. Industrial Management and Data Systems, 115(2), 253-269. https://doi.org/10.1108/IMDS08-2014-0243

Ye, P.-H., \& Liu, L.-Q. (2017). Influence Factors of Users Satisfaction of Mobile Commerce -An Empirical Research in China. Advances in Economics, Business and Management Research, 50, 208-217.

https://doi.org/10.2991/mse-17.2017.50 Yeo, S. F., Tan, C. L., Teo, S. L., \& Tan, K. H. (2021). The role of food apps servitization on repurchase intention: A study of FoodPanda. International Journal of Production Economics, 234(February), 108063.

https://doi.org/10.1016/j.ijpe.2021.10806 